\title{
Molecular characterization of 'Candidatus Phytoplasma solani' in Celery: Case Study in Futog
}

\author{
Tatjana Popović ${ }^{\cdot} \cdot$ Petar Mitrović $^{2} \cdot$ Andrea Kosovac $^{3 *}$ \\ ${ }^{1}$ Institute for Plant Protection and Environment, 11040 Belgrade, Serbia \\ 2 Institute of Field and Vegetable Crops, 21000 Novi Sad, Serbia \\ ${ }^{3}$ Institute of Pesticides and Environmental Protection, 11080 Belgrade, Serbia
}

\begin{abstract}
Summary: 'Candidatus Phytoplasma solani', known by its trivial name stolbur phytoplasma, is a plant pathogen infecting numerous crops in Serbia. Celery plants with prominent leaf yellowing and chlorosis, sporadically with tissue necrosis, were observed during august 2020 in Futog, situated in Novi Sad suburbia in Vojvodina. Total of 12 sampled celery plants, 8 symptomatic and 4 asymptomatic ones, were analysed for ' $\mathrm{Ca}$. P. solani' presence. All symptomatic celery plants were infected with stolbur phytoplasma according to the stol11 gene detection and therefore were further subjected to multigene molecular characterization on three genes: tuf, stamp and vmp1. Combining molecular tools PCR/RFLP and sequencing reviled two ' $C a$. P. solani' multilocus genotypes in celery: tuf-b/Rqg31/V14 and tuf-b/ Rpm35/V14, present in 4 samples each. Obtained results of the strain genotyping are in concordance with previous data on the ' $C a$. P. solani' diversity on celery, but supplemented with genotyping of the $v m p 1$ gene. Outbreak of stolbur phytoplasma in the assessed locality in Futog is linked to tuf-b epidemiological cycle correlated in Serbia mainly with weed Convolvulus arvensis which was present in the subjected celery plot, and could have been the phytoplasma inoculum source. Visual evaluation of the symptom occurrence suggests on 10-15\% of 'Ca. P. solani' affected celery plants scattered throughout the plot corresponding to the pathogen dispersal in crop by cixiid planthoper Hyalesthes obsoletus (Hemiptera: Auchenorrhyncha) associated with C. arvensis, main vector of stolbur phytoplasma in Serbia.
\end{abstract}

Key words: celery, molecular characterization, stolbur phytoplasma

\section{Introduction}

'Candidatus Phytoplasma solani' (stolbur phytoplasma), belonging to the 16 SrXII-A ribosomal subgroup, is fastidious obligate phytopathogenic bacterium endemic in Europe (Quaglino et al., 2013). Successful persistence of stolbur phytoplasma in natural and agroecosystems is possible due to the pathogen's peculiar biology to sustain itself in phloem sieve tubes of host plants and hemolymph of insect vectors (Christensen et al., 2005). Transmission of stolbur

\section{Corresponding author:}

kosovac.andrea@gmail.com

Acknowledgement: The study was funded by the Ministry of Education, Science and Technological Development of the Republic of Serbia (Contracts 451-039/2021-14/ 200010; 451-03-9/2021-14/200032; 451-03-9/2021-14/ 200214).

\section{Cite this article:}

Popović T., Mitrović P., Kosovac A. (2021). Molecular characterization of 'Candidatus Phytoplasma solani' in Celery: Case Study in Futog. Ratar. Povrt., 58 (2), 66-71

\section{(c) (i)}

phytoplasma to natural vegetation, weeds and commercial plants is achieved via insect vectors belonging to the suborder Auchenorrhyncha of the order Hemiptera (leafhoppers and planthoppers) (Alma et al., 2019). Identification and characterisation of ' $\mathrm{Ca}$. P. solani' in plants and insects is based on molecular techniques, PCR (polymerase chain reaction) and RFLP (restriction fragment length polymorphism). Stolbur phytoplasma-specific gene stol11 (Clair et al., 2003) is widely used for unambiguous detection, while gene stamp (stolbur antigenic membrane protein) (Fabre et al., 2011), besides detection, provides an insight into the genetic diversity of the 'Ca. P. solani' strains. Molecular marker that delineates epidemiological pathways of ' $C a$. P. solani'-outbreak is housekeeping gene tuf (elongation factor $\mathrm{Tu}$ ) of which 4 types/genetic variants are so far described in Europe (Langer \& Maixner, 2004; Aryan et al., 2014; Kosovac et al., 2016; 2019; Ćurčić et al., 2021). 'Ca. P. solani' tuf type b1 is linked to the disease outbreaks caused by the activity of the insect vectors Hyalesthes obsoletus (associated with Convolvulus arvensis, Vitex agnus-castus and Crepis foetida) and Reptalus panzeri (Jović et al., 2009; Kosovac et al., 2016; 2019). Tuf types $\mathrm{a}$ and b2 are harbored by Urtica dioica and are dispersed 
by the associated population of the previously noted vector species, $H$. obsoletus. Recently, another tuf type of stolbur phytoplasma was described in Serbia, tuf-d, so far only detected in few crops (sugar beet, parsnip and parsley) in Vojvodina but still lacking data on the host plant/s that source infection (Ćurčić et al., 2021).

Plant diseases caused by ' $C a$. P. solani', with or without revealed epidemiology and corresponding insect vector, were observed in Serbia from the middle of the 20th century on pepper, eggplant, tomato and tobacco (Martinović \& Bjegović, 1950; Aleksić et al., 1967). Occurrence and outbreaks of ' $\mathrm{Ca}$. P. solani' were in the more recent years observed on grapevine (Bois Noir), corn (Corn Reddening/Maize Redness), potato (Potato Stolbur), sugar beet (Rubbery Taproot Disease) etc. (Duduk et al., 2004; Duduk \& Bertaccini, 2006; Jović et al., 2009; Mitrović et al., 2016; Ćurčić et al., 2021). Vojvodina, North Serbian province, is area prone to ' $C a$. P. solani'induced plant diseases where occurrence of all previously noted diseases was recorded. Besides crops where intensive agricultural production and high yields are continuously planned and expected over the years, several other crops and medicinal plants with minor production are also endangered by ' $C a$. P. solani' and recorded in Vojvodina as hosts of stolbur phytoplasma: parsley, carrot, tobacco, evening primrose (Oenothera biennis) etc. (Mitrović et al., 2013; Kiprovski et al., 2018; Mitrović et al., 2021). Celery (Apium graveolens L.) is biannual herbaceous plant belonging to the parsley family (fam. Apiaceae). It is native to the Mediterranean and the Middle East and grown for roots usually consumed in a processed form as a cooked vegetable or as a spice. Celery in Serbia is mainly grown on smaller plots across Vojvodina by the minor producers. First data on the celery infected with 'Ca. P. solani' in Serbia was reported by Ivanović et al. (2011) and referred to Padinska Skela in Belgrade suburbia. Celery infected with ' $C a$. P. solani' was later also detected in central Serbia in towns of Svilajnac and Paraćin (Ćurčić et al., 2021).

During 2020 in Futog, suburban area of Novi Sad, yellowing and chlorosis of the celery plants were observed in a secluded celery growing plot suggesting on phytoplasma infection. Since thorough molecular characterization of the 'Ca. P. solani' strains infecting celery in Serbia was not previously done, presented study will provide an insight into the genetical diversity of the phytoplasma strains infecting this vegetable crop in Vojvodina. This is achieved through multilocus genotypisation of ' $\mathrm{C} a$. P. solani' strains from celery in Futog based on the three marker genes: stamp, tuf and ump1 (variable membrane protein).

\section{Material and methods}

\section{Sample collecting}

In August 2020 in Futog $\left(45^{\circ} 15^{\prime} 34.2^{\prime \prime} \mathrm{N} 19^{\circ}\right.$ $39^{\prime} 46.1$ "E, lat. $77 \mathrm{~m}$ ), on a celery plot of 0.9 ha, celery plants of the altered leaf coloration were noticed (Figure 1). Plants exhibiting symptoms of yellowing and chlorosis of the leaves were sporadically present in the field. Total of 12 samples were collected, 8 symptomatic

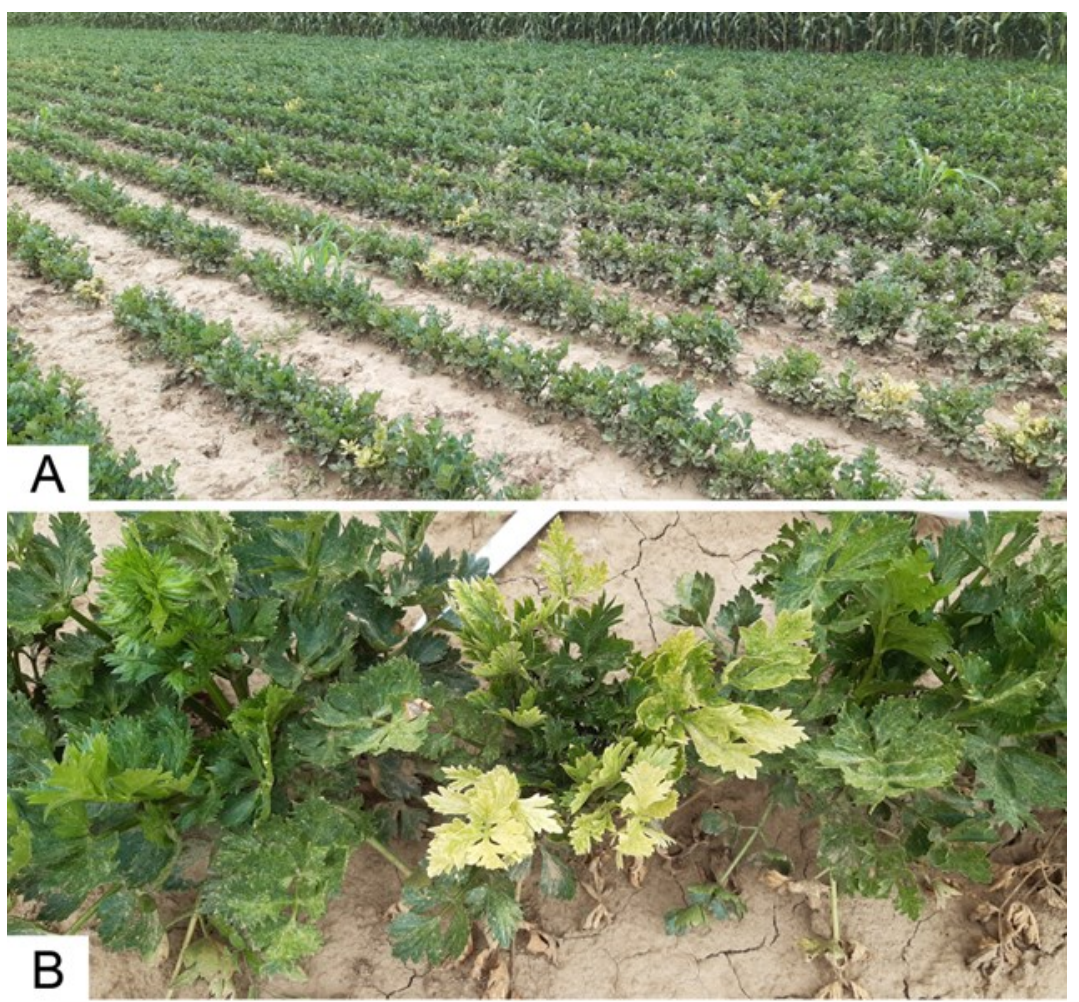

Figure 1. Assessed celery plot in Futog with prominent celery plants expressing yellowing symptoms (A); symptomatic celery plant (B) 
celery plants and 4 asymptomatic ones. Plant leaves were sampled in the field, placed in separate zip plastic bags and stored in the portable refrigerator at $\sim 10^{\circ} \mathrm{C}$ until the return to the laboratory. One gram of the leaf midribs and veins from each sample was placed in a freezer at $-20^{\circ} \mathrm{C}$ until further PCR/RFLP molecular analysis for detection and characterization of ' $C a$. P. solani'.

\section{DNA extraction and molecular identification of} 'Ca P. solani'

Total nucleic acids were extracted from previously prepared samples of celery plants applying the CTAB protocol (Doyle \& Doyle, 1990). DNA was precipitated with isopropanol and diluted in a TE buffer $(10 \mathrm{mM}$ Tris $158 \mathrm{pH} 8$ and $1 \mathrm{mM}$ EDTA). Extracted DNA was finally stored at $-20^{\circ} \mathrm{C}$ until further analysis.

Stolbur phytoplasma was detected by applying nested PCR assay with the ' $C a$. P. solani'-specific primers STOL11F2/R1 and STOL11F3/R2 for amplification of the stol11 gene (Clair et al., 2003), following thermal protocol by the same authors. Total of $25 \mu \mathrm{L}$ of the PCR mix contained $20 \mathrm{ng}$ of template DNA, $1 \times$ PCR Master Mix (Thermo Scientific, Vilnius, Lithuania) and $0.4 \mu \mathrm{M}$ of each primer. One microliter of the direct PCR amplicon diluted $10 \times$ in sterile water was used as a template for the nested reaction. Previously characterized 'Ca. P. solani' strain 429/19 (Ćurčić et al., 2021) was used as positive control in identification analysis, as well as in further characterization of the detected strains. PCR products were further stained with ethidium bromide, separated on $1 \%$ agarose gel in TBE buffer (Tris-borate $90 \mathrm{mM}$, EDTA 1 $\mathrm{mM}$ ) and visualized under a UV transilluminator.

\section{Multilocus characterization of 'Ca P. solani' strains}

All celery samples that were stoll11-positive were further subjected to the molecular characterization combining PCR, RFLP analysis and sequencing of the (1) housekeeping gene tuf and more variable genes (2) stamp and (3) vmp1. Amplification of the tuf gene was performed in nested PCR using Tuf1f/ $r$ in direct and fTufAy/rTufAy in nested reaction (Schneider \& Gibb, 1997). Specific tuf types of 'Ca. P. solani' were determined subjecting nested PCR products to restriction digestion with HpaII and Tai endonuclease (Fermentas) following the manufacturer's instructions. Enzyme HpaII was used for differentiation of the a and $\mathrm{b}$ tuf types, while enzyme TaiI was latter employed to determine whether previously detected $\mathrm{b}$ type bears a mutation that classifies it into the newly described d type (Langer \& Maixner, 2004; Ćurčić et al., 2021). All restriction products were separated in $8 \%$ polyacrylamide gel and obtained profiles were compared with reference ' $C a$. P. solani' strains. Variable stamp gene was amplified in nested PCR reaction applying primer pairs StampF/R0 and StampF1/R1 under the thermal protocol according to Fabre et al., (2011). Nested PCR products were separated in 1\% agarose gel, stained with ethidium bromide and visualized under the UV transilluminator. Nested amplicons were commercially sequenced by Macrogen Inc. (Seoul, Korea) and edited using FinchTV v.1.4.0. (http://www.geospiza.com). Obtained sequences were compared to the previously published ' $\mathrm{Ca}$. P. solani' strains available in the GeneBank NCBI database using a BLASTn algorithm (https:// blast.ncbi.nlm.nih.gov) and ClustalW algorhythm integrated into a MEGA5 software (Tamura et al., 2011). Amplification of the vmp1 gene was also performed in a nested PCR procedure with primers a StolH10F1/R1 for direct and TYPH10F/R for nested PCR (Cimerman et al., 2009; Fialová et al., 2009) following reaction conditions specified by Fialová et al. (2009). Nested products were digested with $\mathrm{Rsa}$ I restriction enzyme (Thermo Scientific) in order to reveal specific RFLP patterns in detected 'Ca. P. solani' strains and visualized in $8 \%$ polyacrylamide gel. As referent strains of the profiles V2, V4 and V14 were used referent 'Ca. P. solani' strains from the DNA collection of the Laboratory of Phytopathology, Institute for Pesticides and Environment Protection in Belgrade.

\section{Results}

\section{Symptom occurrence}

Only symptoms that were present on celery plants in observed plot in Futog were yellowing and chlorosis of the leaves with sporadical necrosis occurrence. Visual inspection of the assessed celery field suggested on 10$15 \%$ of the symptomatic plant incidence. Total of 34 rows of celery plants were present in the field, each containing cca. 180 plants. Six rows that were inspected for the presence of symptomatic celery plants (two border rows and four central ones) have shown similar number of the chlorotic plants varying from 16-30 individuals. Presence of symptomatic plants in a row was erroneous, without any pattern depending on the row's position in a field.

\section{Multilocus genotyping of 'Ca. P. solani' strains}

All 8 symptomatic celery plants were confirmed as 'Ca. P. solani'-positive by successful amplification of the stol11 gene. Four analysed asymptomatic plants were 'Ca. P. solani'-negative and excluded from further molecular characterization (Table 1). Eight 'Ca. P. solani'-positive samples were successfully genotyped on all three genes tuf, stamp and ump1. Sequencing of the stamp gene resulted in detecting two stamp genotypes, Rqg31 and Rpm35, present in 4 analysed samples each. RFLP analysis of the tuf gene revealed presence of only b tuf type in all ' $C a$. P. solani' samples. Both detected stamp genotypes, Rqg31 and Rpm35, belong to the stamp-b genetic cluster, corresponding to the obtained results. Profiles obtained from the RFLP analysis of the vmp1 gene suggested on the presence of V14 type in all ' $\mathrm{Ca}$. P. solani' strains. 
Table 1. List of celery samples analysed for 'Ca. P. solani' presence. Symptomatic samples are coded with acronym "CelS", while asymptomatic ones with "CelA". Infection of the analysed samples with stolbur phytoplasma is noted in column stol11 with acronyms $\mathrm{CaPs}+$ ('Ca. P. solani'-positive) and $\mathrm{CaPs}$ - ('Ca. P. solani'-negative.). Following columns provide data on the specific tuf type, stamp genotype and $v m p 1$ profile determined in analysed samples. Symbol "/" indicates that the corresponding samples were not further analysed on the noted genes.

\begin{tabular}{|c|c|c|c|c|}
\hline Sample ID & $\begin{array}{l}\text { stol11 } \\
\left(\mathrm{CaPs}+/ \mathrm{CaPs}_{-}\right)\end{array}$ & tuf type & stamp genotype & vmp1 profile \\
\hline CelS1 & $\mathrm{CaPs}+$ & tuf-b & Rqg31 & V14 \\
\hline CelS2 & CaPs+ & tuf-b & Rpm35 & V14 \\
\hline CelS3 & CaPs+ & tuf-b & Rqg31 & V14 \\
\hline CelS4 & CaPs+ & tuf-b & Rqg31 & V14 \\
\hline CelS5 & CaPs+ & tuf-b & Rpm35 & V14 \\
\hline CelS6 & CaPs+ & tuf-b & Rpm35 & V14 \\
\hline CelS7 & CaPs+ & tuf-b & Rpm35 & V14 \\
\hline CelS8 & CaPs+ & tuf-b & Rqg31 & V14 \\
\hline CelA1 & CaPs- & / & / & / \\
\hline CelA2 & CaPs- & / & / & / \\
\hline CelA3 & $\mathrm{CaPs}_{\mathrm{s}}$ & / & / & / \\
\hline CelA4 & $\mathrm{CaPs-}$ & / & I & / \\
\hline
\end{tabular}

\section{Discussion}

Crops infected with 'Ca. P. solani' can be encountered throughout Serbia, but are most frequently found in Vojvodina. Grape growing area of Fruška Gora is known for the Bois Noir presence, in southern Banat Corn Reddening/Maize Redness has been observed for more than 50 years with occasional epiphytotics, while in all three regions of Vojvodina: Banat, Bačka and Srem, Rubbery Taproot Disease of sugar beet with recently disclosed etiology is present (Duduk et al., 2004; Jović et al., 2009; Curčić et al., 2021). Results presented in this study have confirmed that celery is crop endangered by ' $C a$. P. solani' in Serbia. 'Ca. P. solani'-infection of celery was so far reported in Hungary, Italy and neighbouring Romania and Bosnia and Herzegovina (Viczián, 2002; Carraro et al., 2008; Chireceanu et al., 2016; Delić et al., 2016). Serious agroeconomic losses of the celery production due to stolbur phytoplasma infection have so far been observed in Italy and correlated to the period of transplanting celery seedling in the open field, reporting $80-90 \%$ of infected plants if transplanted at the end of June/first half of July (Carraro et al., 2008). Interestingly, phytoplasmas of the 16SrI-C subgroup naturally infect celery in Czech Republic and induce phyllody, stunting and severely bushy tops (Fránová \& Spak, 2013), while in Serbia closely related 16SrI-A and 16SrI-B subgroups were detected so far in carrot and broccoli (Duduk et al., 2007).

All analysed celery plants that have exhibited symptoms of yellowing and occasionally necrosis, were infected with stolbur phytoplasma, while asymptomatic ones were not. This confirms that phytoplasma infection in this crop is followed by the changes in the plant physiology possibly similar to the biochemical mechanisms researched in the case of ' $C a$. P. solani'infected carrots in Serbia (Mitrović et al., 2021). Previously reported symptom of ' $C a$. P. solani' on celery, leaf reddening (Ivanović et al., 2011), was not observed in the assessed celery plot in Futog. Occurrence of the symptomatic celery plants was visually assessed and estimated as 10 up to $15 \%$. Symptomatic plants were scattered throughout the field, lacking any pattern in the occurrence. This kind of dispersed disease outbreak in a field suggests that infection source is most probably inside the crop, not in its surrounding. Although several weeds were sporadically present in the field (Sorghum balepenese, Chenopodium bybridum and Portulaca oleracea), prevailing was $C$. arvensis, very common weed in diverse crops in Vojvodina. If $C$. arvensis is present in a field, there is high probability that associated population of the $H$. obsoletus, 'Ca. P. solani' vector, will disperse pathogen through filed which could be the case in Futog.

Multilocus characterization of ' $C a$. P. solani' strains detected in celery in Futog, mainly genotyping of the stamp gene, suggests that detected strains, harbouring Rqg31 and Rpm35 genotypes, could have been introduced into the crop following two scenarios (vectors). Populations of $H$. obsoletus associated with $C$. arvensis, as previously suggested, are known to be infected with strain tuf-b/Rqg31/V14 in Serbia (Kosovac et al., 2019). On the other hand, multilocus genotype tuf-b/Rpm35/V14 was previously detected in another cixiid, Reptalus panzeri originating from corn (Cvrković et al., 2014). Albeit corn was bordering the celery crop along the two sides, thus opening the possibility that $R$. panzeri could be the vector of ' $C a$. P. solani' as occasionally transiting into the celery plot, lack 
of the linear marginal occurrence of the symptomatic celery plants suggests that this epidemiological scenario is in this case probably unlikely. Anyhow, planning of the neighbouring crops in advance should be taken into account as preventive measure. It is important to note that stamp genotypes Rqg31 and Rpm35 were previously detected on celery in central Serbia, as well as genotype Rqg50, all associated with tuf-b types (Ćurčić et al., 2021).

\section{Conclusions}

Celery is a crop with minor production in Serbia, usually grown outdoors in Vojvodina on small plots next to the widely grown maize, wheat and sunflower. Although relatively low level of ' $C a$. P. solani' infection was observed in Futog, agroeconomic losses in crops affected with stolbur phytoplasma can reach up to $80 \%$ (Johannesen et al., 2008). Infection rate of ' $\mathrm{Ca}$. P. solani' in celery, as well as in any other crop, depends on the activity of the insect vector/s and therefore, disease control measures mainly imply control of the insect vector population/s. Since there are not yet widely accepted insecticide strategies for the control of Auchenorrhyncha species, focusing on the removal of the dual host-plants, simultaneously hosting ' $C a$. P. solani' and vector, is precondition for the reduction of the disease incidence. Further research on the Auchenorrhyncha fauna in the celery crops would give an insight into the ' $C a$. P. solani' epidemiology on this crop in Serbia.

\section{References}

Aleksić, Ž., Šutić, D., Aleksić, D. (1967). Transmission intensity of stolbur virus by means of Hyalesthes obsoletus Sign. on some host plants. Zaštita bilja, 93-95, 67-73.

Alma, A., Lessio, F., Nickel, H. (2019). Insects as phytoplasma vectors: ecological and epidemiological aspects. In: Phytoplasmas: Plant Pathogenic Bacteria-II (pp. 1-25). Springer, Singapore.

Aryan, A., Brader, G., Mörtel, J., Pastar, M., and Riedle-Bauer, M. (2014). An abundant 'Candidatus Phytoplasma solani' tuf b strain is associated with grapevine, stinging nettle and Hyalesthes obsoletus. European Journal of Plant Pathology, 140, 213-227.

Carraro, L., Ferrini, F., Martini, M., Ermacora, P., Loi, N. (2008). A serious epidemic of stolbur on celery. Journal of Plant Pathology, 131135.

Chireceanu, C., Chiriloaie, A., Teodoru, A. (2016). Molecular detection of "stolbur" phytoplasma in celery plants in Romania. Phytopathogenic Mollicutes, 6(1), 46-49.

Christensen, N.M., Axelsen, K.B., Nicolaisen, M., Schulz. A. (2005). Phytoplasmas and their interactions with hosts. Trends in Plant Science, 10, 526-535.

Cimerman, A., Pacifico, D., Salar, P., Marzachì, C., Foissac, X. (2009). Striking diversity of Vmp1, a variable gene encoding a putative membrane protein of the stolbur phytoplasma. Applied and Environmental Microbiology, 75, 2951-2957.

Clair, D., Larrue, J., Aubert, G., Gillet, J., Cloquemin, G., Boudon-Padieu, E. (2003). Direct sensitive diagnosis of Flavescence dorée and Bois noir using a multiplex nested-PCR assay and its use in field surveys. Extended abstracts 14th Meeting ICVG, Locorotondo, Italy, 13-17.

Cvrković, T., Jović, J., Mitrović, M., Krstić, O., Toševski, I. (2014). Experimental and molecular evidence of Reptalus panzeri as a natural vector of bois noir. Plant Pathology, 63(1), 42-53.
Curčić, Z., Stepanović, J., Zübert, C., Taški-Ajduković, K., Kosovac, A., Rekanović, E., Kube, M., Duduk, B. (2021). Rubbery taproot disease of sugar beet in Serbia associated with 'Candidatus Phytoplasma solani'. Plant Disease, 105(2), 255-263.

Delić, D., Contaldo, N., Lolić, B., Moravčević, Đ., Bertaccini, A. (2016). First report of 'Candidatus Phytoplasma solani' in pepper and celery in Bosnia and Herzegovina. Journal of Plant Pathology, 98(1).

Doyle, J.J., Doyle, J.L. (1990). Isolation of plant DNA from fresh tissue. Focus, 12, 13-15.

Duduk, B., Botti, S., Ivanović, M., Krstić, B., Dukić, N., Bertaccini, A. (2004). Identification of phytoplasmas associated with grapevine yellows in Serbia. Journal of Phytopathology, 152(10), 575-579.

Duduk, B., Bertaccini, A. (2006). Corn with symptoms of reddening: new host of stolbur phytoplasma. Plant Disease, 90(10), 1313-1319.

Duduk, B., Bulajić, A., Duduk, N., Calari, A., Paltrinieri, S., Krstić, B., \& Bertaccini, A. (2007). Identification of phytoplasmas belonging to aster yellows ribosomal group in vegetables in Serbia. Bulletin of Insectology, 60(2), 341.

Fabre, A., Danet, J.L., Foissac, X. (2011). The stolbur phytoplasma antigenic membrane protein gene stamp is submitted to diversifying positive selection. Gene, 472(1), 37-41.

Fialová, R., Válová, P., Balakishiyeva, G., Danet, J.L., Šafárová, D., Foissac, X., Navrátil, M. (2009). Genetic variability of stolbur phytoplasma in annual crop and wild plant species in South Moravia. Journal of Plant Pathology, 91, 411-416.

Fránová, J., Špak, J. (2013). First report of a 16SrIC phytoplasma infecting celery (Apium graveolens) with stunting, bushy top and phyllody in the Czech Republic. Journal of Phytopathology, 161(9), 666670.

Ivanović, Ž., Trkulja, N., Živković, S., Pfaf Dolovac, E., Dolovac, N., Jović, J., Mitrović, M. (2011). First report of stolbur phytoplasma infecting celery in Serbia. Bulletin of Insectology, 64(Supplement), S239S240.

Johannesen, J., Lux, B., Michel, K., Seitz, A., Maixner, M. (2008). Invasion biology and host specificity of the grapevine yellows disease vector Hyalesthes obsoletus in Europe. Entomologia Experimentalis et Applicata, 126, 217-227.

Jović, J., Cvrković, T., Mitrović, M., Krnjajić, S., Petrović, A., Redinbaugh, M. G., Pratt, R.C., Hogenhout, S.A, Toševski, I. (2009). Stolbur phytoplasma transmission to maize by Reptalus panzeri and the disease cycle of maize redness in Serbia. Phytopathology, 99(9), 10531061.

Kiprovski, B., Đalović, I., Adamović, D., Mitrović, P., MarjanovićJeromela, A., Malenčić, Đ., Popović, T. (2018). Biochemical changes in Oenothera biennis plants infected by 'Candidatus Phytoplasma solani'. Journal of Plant Pathology, 100 (2), 209-214.

Kosovac, A., Radonjić, S., Hrnčić, S., Krstić, O., Toševski, I., Jović, J. (2016). Molecular tracing of the transmission routes of bois noir in Mediterranean vineyards of Montenegro and experimental evidence for the epidemiological role of Vitex agnus-castus (Lamiaceae) and associated Hyalesthes obsoletus (Cixiidae). Plant Pathology, 65, 285-298.

Kosovac, A., Jakovljević, M., Krstić, O., Cvrković, T., Mitrović, M., Toševski, I., \& Jović, J. (2019). Role of plant-specialized Hyalesthes obsoletus associated with Convolvulus arvensis and Crepis foetida in the transmission of 'Candidatus Phytoplasma solani'-inflicted bois noir disease of grapevine in Serbia. European Journal of Plant Pathology, 153 (1), 183-195.

Langer, M., Maixner, M. (2004). Molecular characterisation of grapevine yellows associated phytoplasmas of the stolbur group based on RFLP analysis of non-ribosomal DNA. Vitis, 43, 191-199.

Martinović, M., Bjegović, P. (1950). O nekim bolestima i štetočinama utvrđenim u NR Srbiji u 1949. godini [On some diseases and pests determined in Serbia in 1949]. Zastita bilja, 2, 59-68.

Mitrović, J., Pavlović, S., Duduk, B. (2013). Survey and multigene characterization of stolbur phytoplasmas on various plant species in Serbia. Phytopathologia Mediterranea, 52(3), 434-441.

Mitrović, M., Jakovljević, M., Jović, J., Krstić, O., Kosovac, A., Trivellone, V., Jermini, M., Toševski, I., Cvrković, T. (2016). 'Candidatus Phytoplasma solani' genotypes associated with potato stolbur in Serbia and the role of Hyalesthes obsoletus and Reptalus panzeri (hemiptera, cixiidae) as natural vectors. European Journal of Plant Pathology, 144(3), 619-630. 
Mitrović, P., Đalović, I., Kiprovski, B., Veljović Jovanović, S., Trkulja, V. Jelušić, A., Popović, T. (2021). Oxidative stress and antioxidative activity in leaves and roots of carrot plants induced by Candidatus Phytoplasma solani. Plants, 10(2), 337.

Quaglino, F., Zhao, Y., Casati, P., Bulgari, D., Bianco, P. A., Wei, W. Davis, R. E. (2013) 'Candidatus Phytoplasma solani', a novel taxon associated with stolbur-and bois noir-related diseases of plants. International Journal of Systematic and Evolutionary Microbiology, 63 (8), 2879-2894.

Schneider, B., Gibb, K.S. (1997). Sequence and RFLP analysis of the elongation factor tu gene used in differentiation and classification of phytoplasmas. Microbiology, 143, 3381-3389.
Tamura, K., Peterson, D., Peterson, N., Stecher, G., Nei, M., Kumar, S. (2011). MEGA5: molecular evolutionary genetics analysis using maximum likelihood, evolutionary distance, and maximum parsimony methods. Molecular Biology and Evolution, 28(10), 27312739 .

Viczián, O. (2002). Identification and investigation of phytoplasmas occurring in Hungary by molecular methods. $\mathrm{PhD}$ dissertation, Szent Istvan University, Faculty of Horticulture.

\section{Molekularna karakterizacija 'Candidatus Phytoplasma solani' na celeru: studija u Futogu}

\section{Tatjana Popović ·Petar Mitrović ·Andrea Kosovac}

Sažetak: 'Candidatus Phytoplasma solani', poznata po trivijalnom nazivu stolbur fitoplazma, biljni je patogen koji inficira brojne kulture u Srbiji. Biljke celera sa izraženim žutilom i hlorozom listova, sporadično i sa nekrozom tkiva, uočene su u avgustu 2020. u Futogu, predgrađu Novog Sada u Vojvodini. Ukupno 12 uzoraka celera, 8 simptomatičnih i 4 asimptomatične bilike, analizirane su na prisustvo 'Ca. P. solani'. Svi simptomatični uzorci su se pokazali inficiranim stolbur fitoplazmom na osnovu analize stol11 gena i dalje su molekularno okarakterisani na 3 gena: tuf, stamp i vmp1. Kombinacijom molekularnih tehnika PCR/RFLP i sekvenciranja utvrđeno je prisustvo dva 'Ca. P. solani' multigenska genotipa, tuf-b/Rqg31/V14 i tuf-b/Rpm35/V14, prisutnih u po četiri uzorka. Dobijeni rezultati genotipizacije uzoraka stolbur fitoplazme odgovaraju prethodnim podacima o diverzitetu ovog patogena na celeru u Srbiji i dopunjeni su sa genotipizacijom vmp1 gena. Pojava stolbur fitoplazme u Futogu je vezana za tuf-b epidemiologiju, koja uglavnom izvire iz korovske vrste Convolvulus arvensis (poponac), koja je bila prisutna u istraživanom zasadu celera i mogla je biti izvor inokuluma. Vizuelna procena pojave simptoma pokazala je 10-15\% prisustva simptomatičnih biljaka celera, nepravilno raspoređenih unutar zasada što ukazuje da je odgovorni vektor najverovatnije cikada Hyalesthes obsoletus (Hemiptera: Auchenorrhyncha) asocirana sa poponcem, najznačajniji vektor stolbur fitoplazme u Srbiji.

Ključne reči: celer, molekularna karakterizacija, stolbur fitoplazma 